\title{
АКТИВНІСТЬ КАТЕПСИНІВ В, L, Н У ПЛАЗМІ КРОВІ ПАЦІЄНТІВ ІЗ ХРОНІЧНИМИ ДИФУЗНИМИ ЗАХВОРЮВАННЯМИ ПЕЧІНКИ
}

Вступ. Для діагностики гістологічних стадій хронічних дифузних захворювань печінки поряд із трепанобіопсією широко використовують плазмові маркери.

Мета дослідження - визначити активність цистеїнових катепсинів $B, L, H$ і вміст інгібіторів протеолізу $\alpha_{1}$-антитрипсину та $\alpha_{2}$-макроглобуліну в плазмі крові пацієнтів із хронічними дифрузними захворюваннями печінки невірусної етіології.

Методи дослідження. Об'єкт дослідження - плазма крові пацієнтів із хронічними дифузними захворюваннями печінки (n=51) віком 28-60 років, які перебували на стаціонарному лікуванні у відділенні захворювань печінки та підшлункової залози Інституту гастроентерології НАМН України. Контрольну групу становили здорові волонтери ( $n=15)$ віком від 25 до 52 років. Активність катепсинів $B, L, H$ визначали

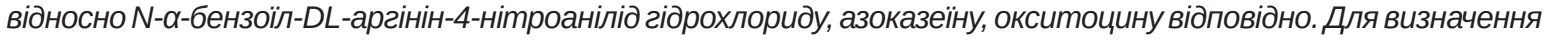
вмісту інгібіторів у плазмі крові як субстрат використовували розчин N- $\alpha$-бензоїл-DL-аргінін-4-нітроанілід гідрохлориду.

Результати й обговорення. Порівняно з групою практично здорових донорів статистично значущі відмінності зафріксовано в таких групах: у пацієнтів із стеатогепатитом активність катепсину В зростала на 26,7\%, а рівень $\alpha_{2}$-макроглобуліну знижувався на 30,7\%; у хворих на хронічний вірусний гепатит 3 переходом у цироз активність катепсину В підвищувалась на 43,8 \%, активність катепсину Н зменшувалась на 35,0\%, а вміст $\alpha_{2}$-макроглобуліну, навпаки, збільшувався на 71,5\%; у пацієнтів із стеатогепатозом активність катепсинів L та Н знижувалась на 22,1 і 25,0 \% відповідно, а концентрація $\alpha_{1}$-антитрипсину зростала на 19,30\%.

Висновок. Визначення рівня інгібіторів разом з активністю цистеїнових катепсинів у плазмі крові можна запропонувати як неінвазивні маркери при хронічних дифузних захворюваннях печінки невірусної етіології.

КЛЮчОВІ СЛОВА: катепсини B, H, L; $\alpha_{1}$-антитрипсин; $\alpha_{2}$-макроглобулін; хронічні дифузні захворювання печінки; серологічні біомаркери фріброзу.

ВСТУП. Хронічні диорузні захворювання печінки (ХДЗП) виникають під впливом різних етіологічних фракторів, таких, як уроджені, метаболічні, вірусні, запальні процеси, харчові або медикаментозні токсини тощо $[1,2]$. КлючовоюстадієюХДЗПєфріброз, щосупроводжується активацією зірчастих клітин та їх переходом у клітини з високою фріброгенною активністю 3 посиленням продукування екстрацелюлярного матриксу (ЕЦМ), вміст якого збільшується в 3-10 разів [3]. З іншого боку, для ХДЗПхарактерне вивільнення ензимів, що руйнують ЕЦМ, зокрема матриксних металопротеїназ, цистеїнових катепсинів та їх інгібіторів тощо [4].

(c) Г. В. Долгіх, Г. С. Маслак, В. І. Діденко, І. А. Кленіна, О. Є. Абраімова, 2020.
Цистеїнові катепсини локалізовані в лізосомах, де і виконують свою основну біологічну фрункцію, а при патологічних станах секретуються в позаклітинне середовище, деградують протеїни та руйнують компоненти базальних мембран і матриксу. Катепсини L і B активно залучені в процеси деградації ЕЦМ сполучної тканини за умов фріброзу легень, серцево-судинних захворювань та остеопорозу. Причому катепсин L більшою мірою, ніж катепсин В, проявляє еластолітичну, колагенолітичну і протеогліканолітичну дію. Відомо, що ці тіолпротеази впливають на активацію та проліфрерацію зірчастих клітин легень, їх диференціацію в міофібробласти і контролюють процеси фріброгенезу [5]. Вплив 
катепсину В на некроз та апоптоз гепатоцитів доведено в модельних експериментах [6]. Катепсин Н при гепатиті модулює експресію/ супресію генів матриксних металопротеїназ у клітинах печінки, що сприяє накопиченню ЕЦМ та фрібрилогенезу [7]. Слід також зазначити, що останнім часом зросла кількість робіт, в яких обговорюють прогностичне значення рівня цистеїнових катепсинів при онкологічних процесах $[8,9]$. Отже, на сьогодні роль тавплив цистеїнових катепсинів на патологічні процеси печінки $€$ безумовними, але досі відкритими залишаються питання щодо їх діагностичної значущості в крові хворих із запальними процесами.

Близько 10 \% від загального вмісту функціонально активних протеїнів плазми крові становлять ендогенні інгібітори протеолізу, серед яких $\alpha_{1}$-антитрипсин $\left(\alpha_{1}\right.$-АТ) та $\alpha_{2}$-макроглобулін $\left(\alpha_{2}-\mathrm{M}\right) . \alpha_{2}$-макроглобулін $€$ протеїном гострої орази та має ділянки зв'язування з протеїназами всіх відомих класів, у тому числі фракторів росту, включаючи трансформуючий фрактор росту $\beta$, основний фрактор росту фрібробластів, тромбоцитарний фрактор росту, інтерлейкіни тощо. $\alpha_{1}$-антитрипсин також $€$ протеїном гострої фрази, переважно продукується гепатоцитами і секретується у кров [10]. Десріцит секреції $\alpha_{1}$-АТ пов'язаний із хворобами легень і печінки. У пацієнтів зі зниженим рівнем $\alpha_{1}$-АТ значно активується нейтрофрільна еластаза, що призводить до руйнування сполучної тканини легень і, в кінцевому підсумку, до емфіземи. Американські вчені на мишачих моделях довели, що введення $\alpha_{1}$-антитрипсину знижує еластазаіндукуючий синтез катепсину В і матриксних металопротеїназ-2 та їх активність. Відомо також, що захворювання печінки, викликані агрегацією та утриманням $\alpha_{1}$-АТ в ендоплазматичній мережі, можуть призвести до фріброзу і гепатоцелюлярної карциноми [11].

За фрізіологічних умов протеолітичну активність регулюють інгібітори, завдяки чому зберігається динамічна рівновага, яка зміщується при патологічному процесі. При цьому змінюється активність як обох компонентів рівноваги, так і окремих його складових.

3 огляду на вищенаведені літературні дані, метою роботи було дослідити активність плазмових катепсинів B, L, H і вміст інгібіторів протеолізу $\alpha_{1}$-антитрипсину та $\alpha_{2}$-макроглобуліну, оцінити значимість цихпоказників для діагностики хронічних дифузних захворювань печінки невірусної етіології, а саме: неалкогольної жирової хвороби печінки (стеатозу), стеатогепатиту, алкогольної хвороби печінки, медикаментозного гепатиту і хронічного гепатиту з переходом у цироз.
МЕТОДИ ДОСЛІДЖЕННЯ. Об'єКТ ДОслідження - плазма крові пацієнтів із хронічними дифузними захворюваннями печінки ( $n=51)$ віком 28-60 років, які перебували на стаціонарному лікуванні у відділенні захворювань печінки та підшлункової залози Інституту гастроентерології НАМНУкраїни. Це, зокрема, хворі нанеалкогольну жирову хворобу печінки стеатогепатоз (ХС3) 12 пацієнтів, хворі на стеатогепатит (ХСТ) 13 пацієнтів, хворі на медикаментозний гепатит (ХМГ) - 6 пацієнтів, хворі на алкогольний гепатит (ХАГ) - 5 пацієнтів, хворі на хронічний гепатит 3 переходом у цироз (ХГЦ) - 15 пацієнтів. Контрольну групу становили 15 практично здорових донорів-волонтерів (ПЗД) віком від 25 до 52 років. Забір крові у пацієнтів проводили вранці в один і той самий час з ліктьової вени натщесерце в кількості 15 мл. Для цього використовували одноразові пробірки з антикоагулянтом К або К -ЕДТА, колір кришки пробірки - фріолетовий. Дослідження виконано з дотриманням біоетичних норм відповідно до положень ВООЗ, Гельсінської декларації Генеральної асамблеї Всесвітньої медичної асоціації (1989), Конвенції Ради Європи про права людини та біомедицину (1977), Міжнародної ради медичних наукових товариств, Міжнародного кодексу медичної етики (1983), діючих законів України, що засвідчив комітет з біоетики Дніпропетровської медичної академії Міністерства охорони здоров'я України.

Активність катепсину Н визначали за модифрікованим методом Бредшоу [12], основаним на визначенні продуктів гідролізу білкового субстрату окситоцину (ВАТ “Гедеон Ріхтер”, Угорщина) при довжині хвилі 570 нм. Активність ензиму виражали в мкмоль лейцину, що утворився в процесі гідролізу окситоцину, на 1 мг протеїну за 1 хв при $37^{\circ} \mathrm{C}$.

Активність катепсину В визначали в 1,0 мл інкубаційної суміші (0,1 M K-Na-фросфратний буфрер, pH 6,0 та 0,2 М фросфратний бусрер, pH 6,8)

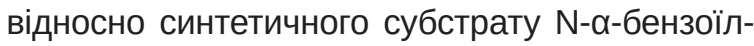
DL-аргінін-4-нітроанілід гідрохлориду ("SigmaAldrich", США). Час інкубації становив 1 год. Активність ензиму виражали в мкмоль паранітроаніліну, що відщепився від субстрату, за 1 год інкубації на 1 мл плазми крові. Рівень протеїну в зразках визначали за методом Бредфрорда [13].

Активність катепсину $L$ визначали в 0,75 мл інкубаційної суміші (0,066 M K-Na-фросфратний бусрер, pH 5,0) відносно азоказеїну ("SigmaAldrich", США), 6 \% розчин якого було попередньо денатуровано 6 М сечовиною. Після двогодинної інкубації реакцію зупиняли 10 \% розчином трихлороцтової кислоти. Активність ензиму виражали в умовних одиницях абсорбції низькомо- 
лекулярних пептидів, що утворюються за 1 год інкубації та не осаджуються трихлороцтовою кислотою, на 1 мл плазми крові. Оптичну щільність зразків досліджуваних рідин визначали за допомогою планшетного спектрофротометра "Humareader" (“Human”, Німеччина, 2001).

Для визначення вмісту $\alpha_{1}$-антитрипсину та $\alpha_{2}$-макроглобуліну в плазмі крові як субстрат використовували 0,001 М розчин N- $\alpha$-бензоїлDL-аргінін-4-нітроанілід гідрохлориду в 0,05 M фоссратному буфрері з рН 7,6. Ензимом протеолізу був трипсин, для цього кристалічний препарат розводили фоссратним буфером до робочої концентрації 50 та 200 мкг/мл відповідно. Після додавання до досліджуваної плазми робочого розчину трипсину суміш витримували протягом 15 хв для утворення комплексу ензим - інгібітор плазми, потім додавали субстрат, інкубували при $37{ }^{\circ} \mathrm{C}$ протягом 30 хв. Реакцію зупиняли $5 \%$ розчином фросфрорновольфрамової кислоти в 1 М ацетатному бусрері 3 pH 4,5. Осад, що утворився, осаджували шляхом центрифугування на центрифуззі марки MPW-55 (Польща) при $\mathrm{g}=6000$ об./хв протягом 15 хв. Супернатант відбирали, вимірювали оптичну щільність при довжині хвилі 383 нм на спектрофротометрі марки ULAB 102 UV (Shanghai Metash Instruments Co., Ltd, Китай, 2018). Для ідентифікації результатів експерименту будували калібрувальну криву.

Статистичну обробку проводили за допомогою програмних пакетів Microsoft Excel 2016, R та EasyROC 1.3.1. Відповідність розподілу кількісних ознак нормальному закону перевіряли за критерієм Шапіро-Уїка. Заумов нормального розподілу даних для опису міри центральної тенденції кількісних ознак використовували середню арисрметичну (X) і стандартну похибку середньої величини (SE). Для оцінки різниці кількісних значень між групами застосовували критерій Тьюкі з поправкою Бонсрерроні. Для аналізу взаємозв'язку між ознаками проводили кореляційний аналіз із розрахунком парних коесріцієнтів кореляції Пірсона та коефріцієнтів рангової кореляції Спірмена. Показник рівня статистичної значимості для всіх видів аналізу дорівнював 5 \%. Розбіжностівважали статистично значущими, якщо ймовірність випадкового виникнення відмінностей не перевищувала 0,05 ( $p<0,05)$. ROC-аналіз та візуалізацію ROC-кривих здійснювали у програмному пакеті EasyROC 1.3.1. Значення площі під ROC-кривою інтерпретували в показниках діагностичної точності: 0,9-1,0 - відмінна, 0,8-0,9 - дуже добра, 0,7-0,8 - добра, 0,6-0,7 - середня, 0,5-0,6 незадовільна; значення 0,5 відповідає непридатності моделі. Точка відсікання розрахована за методом Йодена [14]. Для побудови графріків box-plot використовували програмний пакет статистичної обробки даних R.

РЕЗУЛЬТАТИ Й ОБГОВОРЕННЯ. У біЛЬШОСТі груп пацієнтів із ХДЗП активність катепсину В (У мкмоль паранітроаніліну/год/мл) у плазмі крові не змінювалась. Достовірне зростання на 43,8 та $26,7 \%(p<0,05)$ відзначено в групі хворих на хронічний вірусний гепатит з переходом у цироз і пацієнтів із стеатогепатитом, воно становило

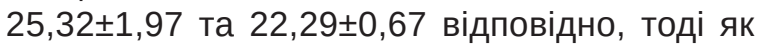

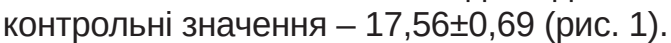

Аналіз активності катепсину $L$ (в умовних одиницях абсорбції/год/мл) у плазмі крові пацієнтів із ХДЗП показав зниження цього показника на $22,1 \%(p<0,05)$ у групі хворих на стеатогепатоз відносно контролю, воно становило, відповідно, $0,563 \pm 0,026$ та 0,723 $\pm 0,015$. В інших групах хворих значних змін активності катепсину $L$ не було виявлено (рис. 2).

Для катепсину Н, навпаки, було зафріксовано однакове зниження активності на 25,0 \% $(p<0,05)$ у групах хворих на стеатогепатоз та медикаментозний гепатит відносно контрольних значень. Так, цей показник (у мкмоль лейцину/год/мл) у групі пацієнтів із стеатогепатозом становив 346,8 $\pm 12,6$, 3 медикаментозним гепатитом $344,4 \pm 9,9$, у контрольній групі - 463,2 $\pm 14,4$. Найбільше зниження (на 35,0 \%, p<0,05) відзначено в групі хворих на хронічний гепатит з переходом у цироз, воно становило 299,5 $\pm 8,9$ (рис. 3).

Відомо, що катепсини B, L, Н беруть участь в обміні внутрішньоклітинних протеїнів, ремоделюванні паренхіми і судин у печінці. Цистеїнові катепсини є потужним класом протеаз, які розщеплюють різні компоненти ЕЦМ, включаючи еластин, протеоглікани, ламінін, колаген, срібронектин [15] та інші структурні компоненти, під час загоєння ран, при атеросклерозі, серцевому, легеневому і нирковому фоброзах [16]. Як правило, ці катепсини локалізовані в лізосомах, де і виконують свою основну біологічну фрункцію. Але при патологічних станах вони можуть виходити в позаклітинне середовище, руйнувати компоненти базальних мембран, деградувати позаклітинні протеїни та інші складові [17]. Так, при злоякісній трансформації, замість того, щоб транспортуватися в лізосоми, катепсини часто переносяться на поверхню клітини і секретуються унавколишнє середовищеувиглядіпопередників, які значно більш стабільні й менш схильні до дії ендогенних інгібіторів, ніж зрілі ензими. Така позаклітинна локалізація цистеїнових катепсинів часто збігається з їх підвищеною експресією та/або активністю в плазмі, що вказує на те, що рН не є єдиним чинником, відповідальним за їх активність [18]. Отже, активність цистеїнових 


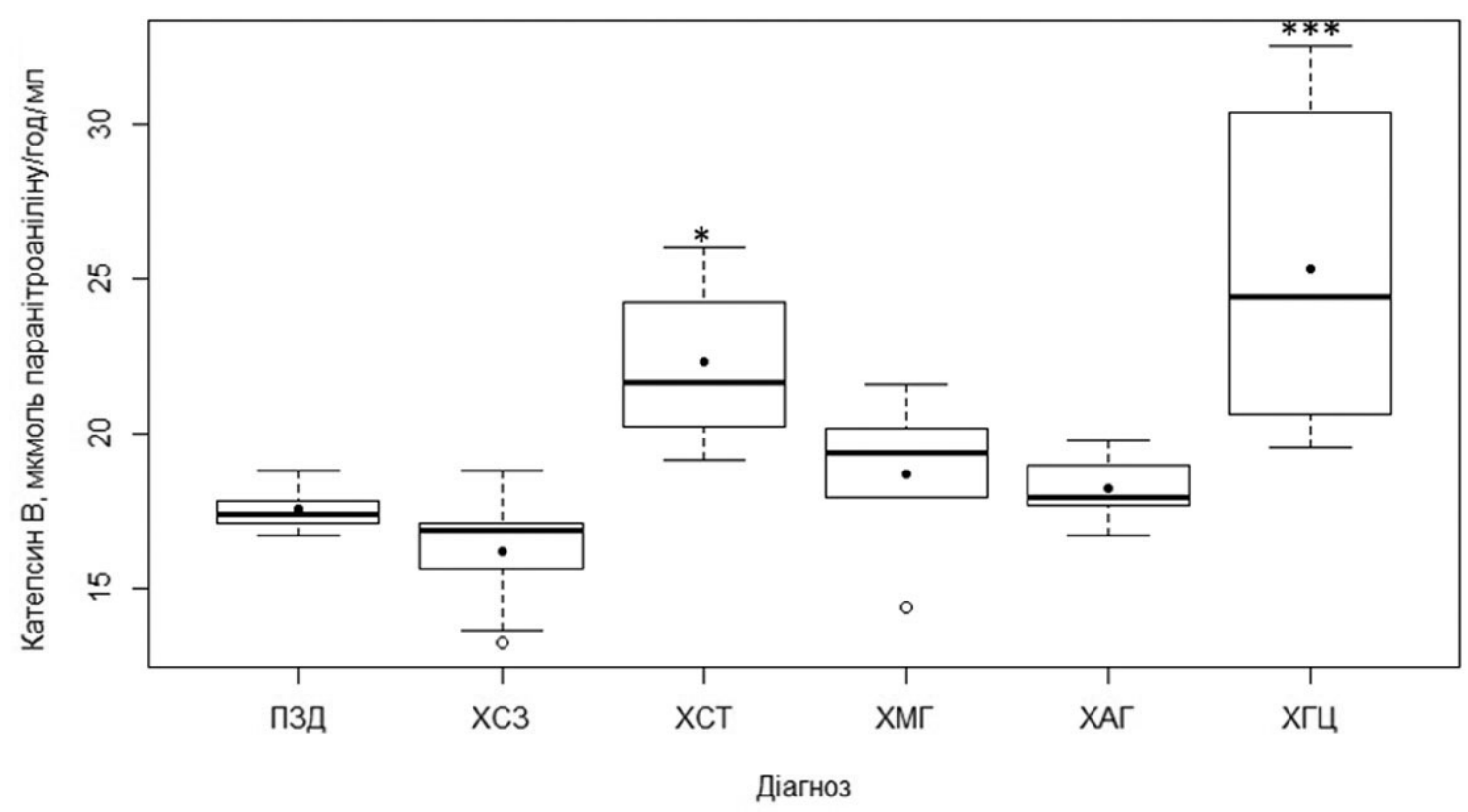

Рис. 1. Активність катепсину В у плазмі крові пацієнтів із хронічними дифрузними захворюваннями печінки. Примітки:

1. Тут і на рисунках 2, 3: ПЗД - практично здорові донори; ХC3 - хворі на стеатогепатоз; ХСТ - хворі на стеатогепатит; ХМГ - Хворі на медикаментозний гепатит; ХАГ - хворі на алкогольний гепатит; ХГЦ - хворі на хронічний гепатит 3 переходом у цироз.

2. * - розбіжності статистично значущі порівняно з контролем $(p<0,05)$; *夫 - розбіжності статистично значущі порівняно з контролем $(p<0,001)$.

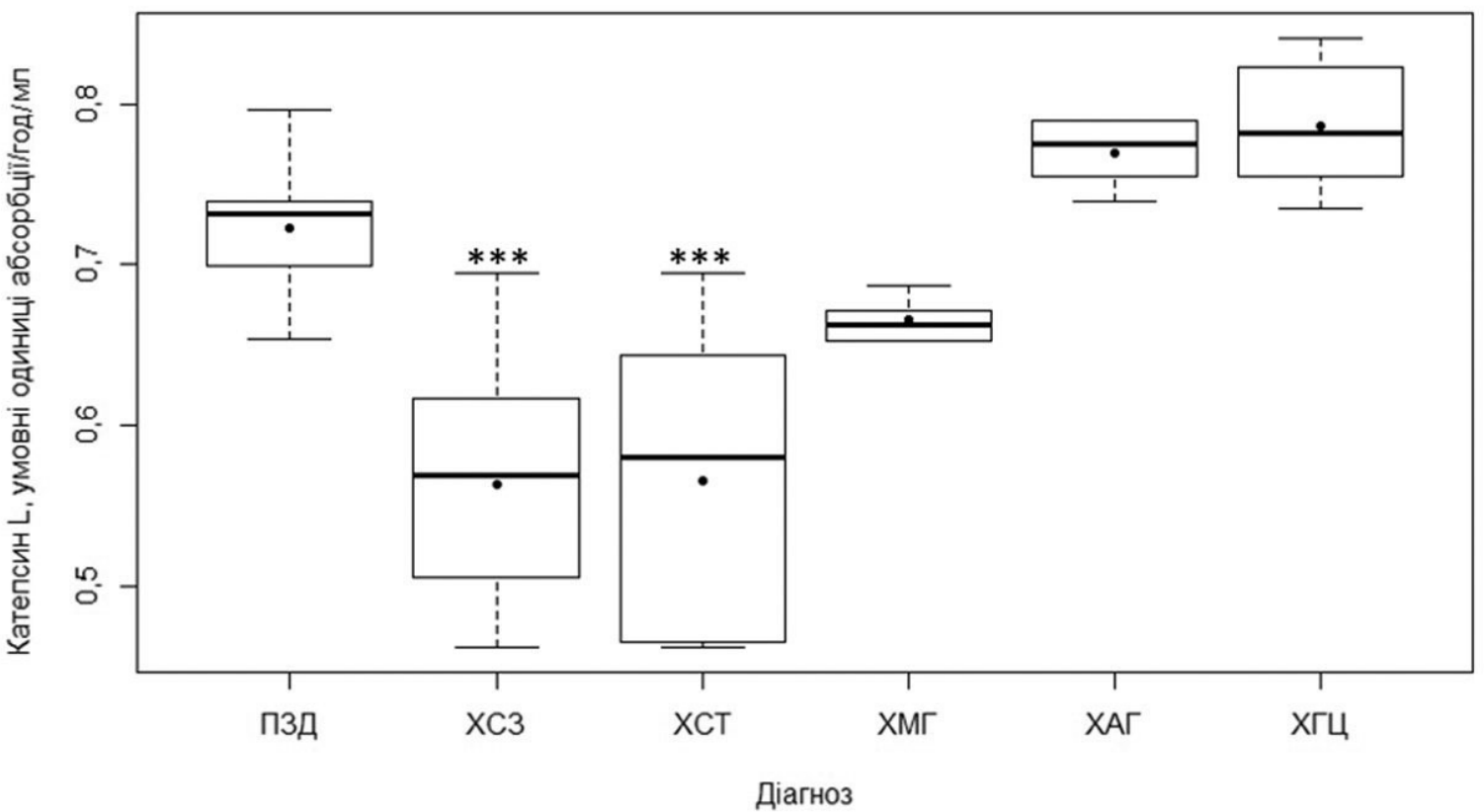

Pис. 2. Активність катепсину L у плазмі крові пацієнтів із хронічними дифузними захворюваннями печінки (див. рис. 1). Примітка. *** - розбіжності статистично значущі порівняно з контролем $(\mathrm{p}<0,001)$.

катепсинів визначають не тільки в клітинній фрракції, але й у плазмі крові.

За отриманими в роботі результатами, в плазмі крові, порівняно з групою практично здорових донорів, найбільші відмінності зафріксовано в групах хворих на стеатогепатоз, стеатогепатит та хронічний гепатит з переходом у цироз. А саме: в пацієнтів із стеатогепатитом активність катепсину В зростала на 26,7%; у хворих нахронічний вірусний гепатит з переходом у цироз активність катепсину В підвищувалась на 43,8 \%, а активність катепсину Н знижувалась на 35,0 \%; у пацієнтів із стеатогепатозом активність катепсинів $L$ та $\mathrm{H}$ зменшувалась на 22,1 i 


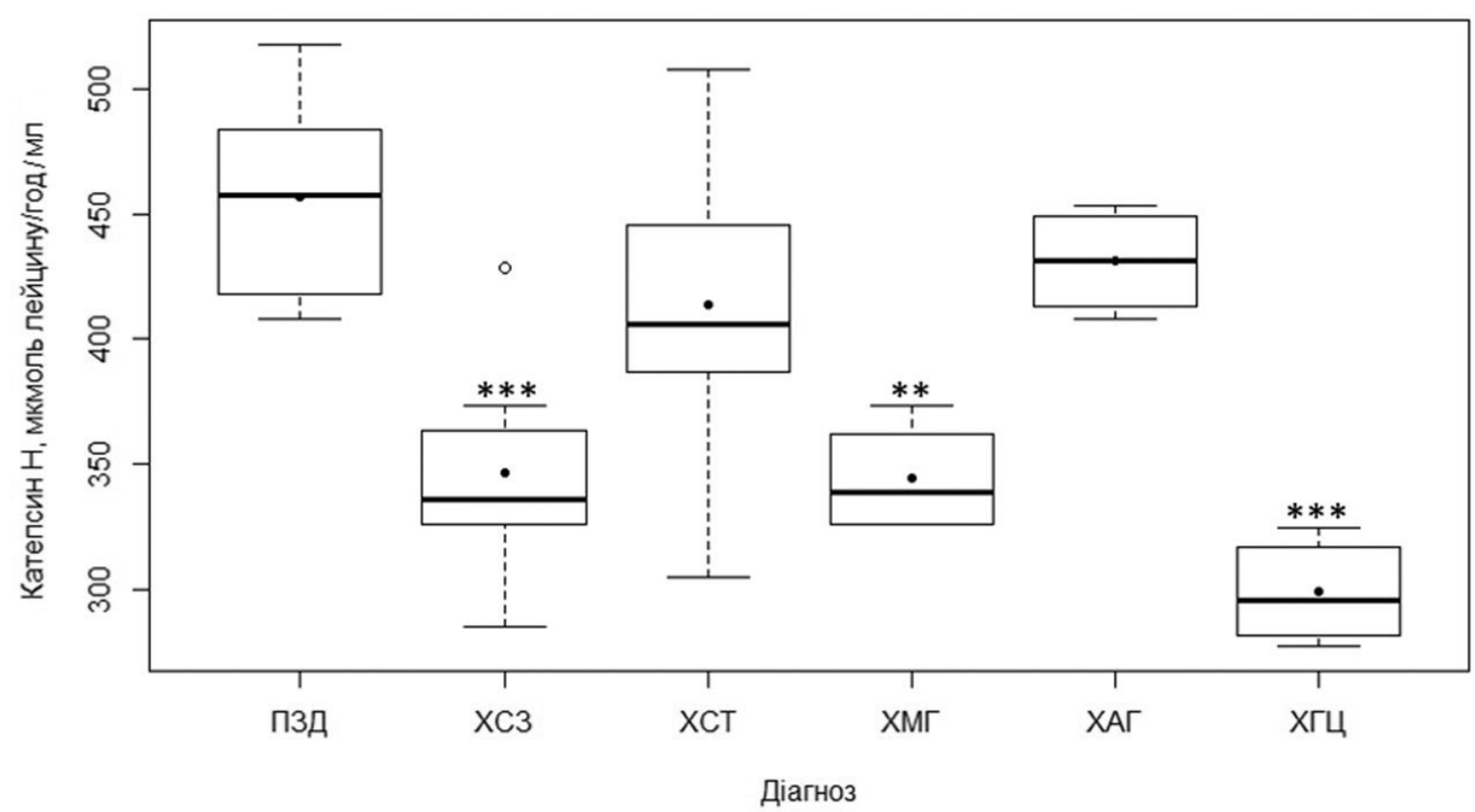

Рис. 3. Активність катепсину Н у плазмі крові пацієнтів із хронічними дифузними захворюваннями печінки (див. рис. 1).

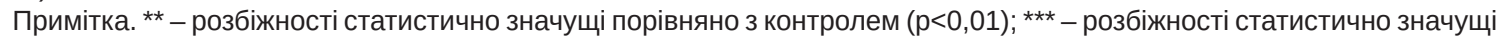
порівняно з контролем ( $p<0,001)$

25,0 \% відповідно; у хворих на медикаментозний гепатит активність катепсину Н достовірно знижувалась на 25,0 \%.

При порівнянні показників активності цистеїнових катепсинів за допомогою тесту Тьюкі 3 поправкою Бонсрерроні виявлено статистично значущі розбіжності міждеякими досліджуваними групами. Для катепсину В розбіжності зафіксовано між групою ХГЦ та практично всіма іншими групами: ХСЗ, ХМГ, ХАГ, ПЗД (р<0,001); також статистично значущі розбіжності відзначено між групами XC3 та XCT (p<0,001). Для катепсину L статистично значущі розбіжності виявлено між групою ХСЗ і групами ПЗД, ХАГ, ХГЦ (р<0,001), між групою ХСТ і групами ПЗД, ХАГ, ХГЦ $(p<0,0001)$, а також між групами ХМГ та ХГЦ $(p<0,05)$. Для катепсину Н статистично значущі розбіжності засріксовано між групою ХГЦ та групами ХCT, ХАГ $(p<0,001)$, а також між групами ХСЗ і ХМГ та ПЗД $(p<0,001)$. Таким чином, наведені порівняння свідчать про те, що активність усіх досліджуваних катепсинів значно змінюється залежно від групи ХДЗП.

При проведенні аналізу побудованих ROC-кривих досліджуваних катепсинів установлено значення показників чутливості (Se) та специфрічності (Sp) тестів; для характеристики інсрормативності визначено площу під ROC-кривою (AUC - Area Under Curve), встановлено точки відсікання для стану норма - патологія. Грасріки ROC-кривих для катепсинів B, L, H наведено на рисунку 4.
Для катепсину B: Se=0,516; Sp=1,0. Точка відсікання відповідає значенню 19,13; таким чином, значення, які перевищують цей показник, можуть вказувати на наявність патологічного процесу (індекс Йодена дорівнює 0,516). $A \cup C=0,71 \quad(p=0,0185)$, що свідчить про добру діагностичну інсрормативність методу. Для катепсину L: Se=1,0; $\mathrm{Sp}=0,568$. Точка відсікання дорівнює 0,700 ; значення, нижчі за цей показник, можуть вказувати на наявність патологічного процесу (індекс Йодена дорівнює 0,568). $A \cup C=0,72(p=0,0092)$, що свідчить про добру діагностичну інфоормативність методу. Для катепсину H: $\mathrm{Se}=1,0 ; \mathrm{Sp}=0,633$. Точка відсікання відповідає значенню 408,2; значення, нижчі за цей показник, можуть вказувати на наявність патології (індекс Йодена дорівнює 0,633). $A \cup C=0,86(p=0,0004)$, що свідчить про дуже добру діагностичну інформативність методу.

Підвищення експресії мРНК та активності катепсинів B i L при оріброзі в людини нещодавно показали вчені з Індії. За їх даними, отриманими в експериментах на мишах $3 \mathrm{CCl}_{4}$-індукованим фріброзом, збільшення активності катепсинів В та $L$ у плазмі крові й зростання їх експресії в печінці позитивно корелювали з рівнем колагену в цьому органі [19]. Взаємозв'язок між даними показниками було підтверджено в інших роботах. При ішемічно-реперфузійному ушкодженні печінки в мишей гальмування синтезу катепсину В знижує накопичення компонентів ЕЦМ [20]. Однак дані щодо змін активності цих протеїнів 

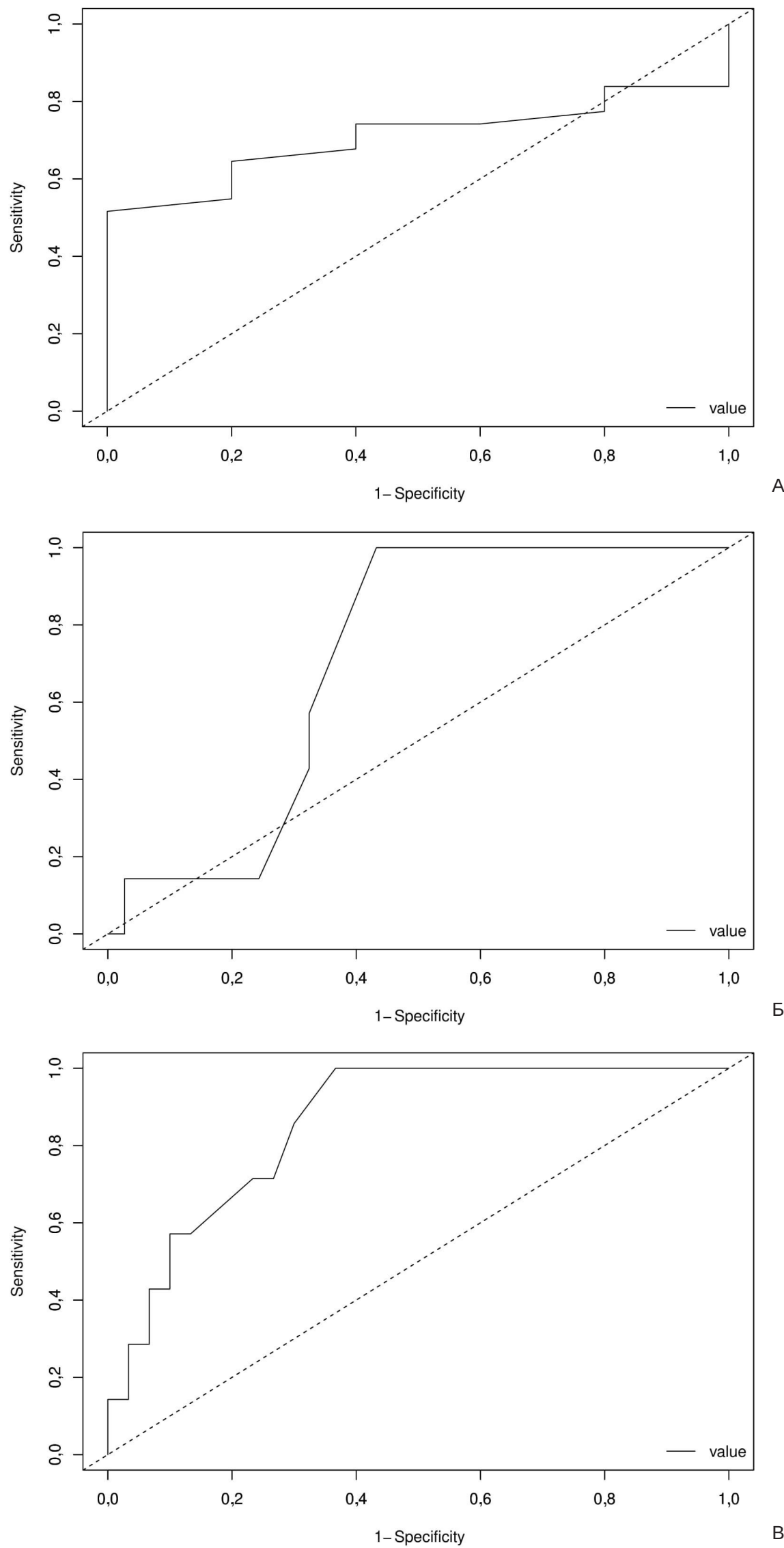

Pиc. 4. ROC-криві використання показників активності цистеїнових катепсинів у плазмі крові для діагностики хронічних захворювань печінки: A - катепсину B; Б - катепсину L; B - катепсину H. 
при хронічних дифуззих захворюваннях печінки невірусної етіології в літературі відсутні. Літературних джерел про рівень експресії катепсину Н та його роль при фрібролітичних порушеннях печінки є небагато. Так, Z. Yang та співавт., використовуючи 3D-модель клітинної культури цирозної тканини печінки, довели, що м'який ЕЦМ індукує експресію цистеїнових катепсинів (особливо катепсину Н), які здійснюють протеоліз протеїнів HDAC класу IIa, переводячи мезенхіальні та зірчасті клітини печінки в епігенетично пермісивний стан, на що вказує підвищення експресії матриксних металопротеїназ у відповідь на сигнали ушкодження. I навпаки, в жорсткій фріброзній стромі цистеїнові катепсини гальмуються, що призводить до накопичення протеїнів HDAC класу Ila і гальмування експресії генів матриксних металопротеїназ на користь тканинного фріброзу [7]. Цікаво, що, за отриманими в нашій роботі даними, активність катепсину Н у крові значно знижувалася, що свідчило на користь теорії Z. Yang та, можливо, може вказувати на тяжкість фрібролітичного порушення печінки у хворих на ХДЗП.

Відомо, що $\alpha_{1}$-антитрипсин та $\alpha_{2}$-макроглобулін $є$ протеїнами гострої фрази, а їх рівень у крові може швидко збільшуватися у відповідь на запалення або інфекцію. Отже, їх концентрація може змінюватись при стеатогепатозі, різних видах гепатитів, цирозі печінки. Також відомо, що рівень даних інгібіторів у плазмі крові може бути знижений. Наприклад, для $\alpha_{1}$-АТ це можливо як при спадковому десріциті, так і при втраті загального протеїну організмом, зокрема при печінковій недостатності. Генетичний дефріцит $\alpha_{1}$-антитрипсину пов'язаний із синтезом мутантного Z-протеїну $\alpha_{1}$-AT у печінці, схильного до спонтанної полімеризації, що помітно ускладнює його вивільнення у кровотік, запускає каскад внутрішньоклітинного ушкодження, яке призводить до ушкодження печінки загалом, зокрема хронічного гепатиту, цирозу і гепатоцелюлярного раку [21]. За отриманими в роботі даними, в пацієнтів із хронічними дисрузними захворюваннями печінки рівень $\alpha_{1}$-АТ у плазмі крові загалом коливався в межах від 27,3 до 78,7 мкмоль/л. Зниження рівня спостерігали у 8-ми пацієнтів $(22,2 \%)$, підвищення - у 22-х (61,1%), нормальний рівень відзначали в 6-ти хворих (16,7 \%). Найбільшу кількість пацієнтів зі зниженою концентрацією $\alpha_{1}$-АТ у плазмі крові (50 \%) виявлено в групах хворих на стеатогепатит (5 з 10-ти) та хронічний гепатит з переходом у цироз (3 із 6-ти). Статистично значуще $(p<0,05)$ зростання концентрації $\alpha_{1}$-АТ зафріксовано в групах пацієнтів із стеатогепатозом (19,3\%), медикаментозним гепатитом (21,8\%), алкогольним гепатитом (18,5 \%) (табл.).

Зниження рівня $\alpha_{2}-\mathrm{M}$ було виявлено у хворих практично всіх досліджуваних груп. Максимальне зменшення вмісту (на 30,7 \%) зафріксовано у пацієнтів із стеатогепатитом; розбіжності показників $\alpha_{2}-$ М у цій групі та групі практично здорових донорів були статистично значущими ( $<<0,05)$. В інших групах пацієнтів із ХДЗП відзначено статистично незначуще зниження рівня інгібітора. Різке підвищення концентрації $\alpha_{2}-\mathrm{M}$ до 71,5 \% $(p<0,05)$ засріксовано в групі хворих на хронічний гепатит з переходом у цироз.

Таблиця - Статистичні характеристики вмісту інгібіторів $\alpha_{1}$-антитрипсину та $\alpha_{2}$-макроглобуліну в плазмі крові пацієнтів із хронічними дифузними захворюваннями печінки

\begin{tabular}{|c|c|c|c|c|}
\hline $\begin{array}{l}\text { Характеристика груп } \\
\text { обстежених осіб }\end{array}$ & $\mathrm{X} \pm \mathrm{SE}$ & $\begin{array}{l}\text { Медіана } \\
\text { Ме }\end{array}$ & $\begin{array}{l}\text { Міжквартильний } \\
\text { розмах [25-75 \%] }\end{array}$ & Min-Max \\
\hline \multicolumn{5}{|c|}{$\alpha_{1}$-антитрипсин, мКмоль/л } \\
\hline $\begin{array}{l}\text { Контрольна група практично здорових } \\
\text { донорів }(n=15)\end{array}$ & $57,8 \pm 1,7$ & 58,4 & $55,9-60,2$ & $51,6-62,9$ \\
\hline Хворі на стеатогепатоз $(\mathrm{n}=8)$ & $69,3 \pm 2,0$ & 69,3 & $67,4-72,2$ & $57,9-78,7$ \\
\hline Хворі на стеатогепатит $(n=10)$ & $52,3 \pm 4,2$ & 57,5 & $43,3-64,0$ & $27,3-67,1$ \\
\hline Хворі на медикаментозний гепатит (n=6) & $70,1 \pm 2,1$ & 70,6 & $66,9-72,2$ & $62,5-78,7$ \\
\hline Хворі на алкогольний гепатит (n=5) & $68,2 \pm 1,4$ & 68,1 & $66,0-70,4$ & $63,9-72,7$ \\
\hline $\begin{array}{l}\text { Хворі на хронічний гепатит з переходом } \\
\text { у цироз }(n=6)\end{array}$ & $49,5 \pm 4,6$ & 48,0 & $42,8-59,2$ & $32,3-64,8$ \\
\hline \multicolumn{5}{|c|}{$\alpha_{2}$-макроглобулін, г/л } \\
\hline $\begin{array}{l}\text { Контрольна група практично здорових } \\
\text { донорів }(n=15)\end{array}$ & $2,25 \pm 0,07$ & 2,21 & $2,10-2,38$ & $2,03-2,51$ \\
\hline Хворі на стеатогепатоз $(\mathrm{n}=8)$ & $1,51 \pm 0,06$ & 1,47 & $1,42-1,57$ & $1,31-1,86$ \\
\hline Хворі на стеатогепатит $(\mathrm{n}=10)$ & $1,96 \pm 0,05$ & 1,92 & $1,86-2,03$ & $1,74-2,30$ \\
\hline Хворі на медикаментозний гепатит (n=6) & $1,90 \pm 0,06$ & 1,88 & $1,78-2,03$ & $1,72-2,13$ \\
\hline Хворі на алкогольний гепатит (n=5) & $1,84 \pm 0,05$ & 1,86 & $1,76-1,92$ & $1,67-1,98$ \\
\hline $\begin{array}{l}\text { Хворі на хронічний гепатит з переходом } \\
\text { у цироз }(\mathrm{n}=6)\end{array}$ & $3,77 \pm 0,21$ & 3,79 & $3,46-4,18$ & $2,97-4,44$ \\
\hline
\end{tabular}


При оцінці відмінності кількісних значень виявлено статистично значущі розбіжності між досліджуваними групами. Для вмісту $\alpha_{1}$-антитрипсину - між групою ХСТ та групами ХАГ і ХМГ $(p<0,05)$, групою ХГЦ і групою ХАГ $(p<0,05), a$ також між групами ХСЗ і ХСТ та групою ХГЦ $(p<0,01)$. Для вмісту $\alpha_{2}$-макроглобуліну - між групою ХГЦ та всіма іншими досліджуваними групами $(p<0,001)$, а також між групою ХСЗ і групою ПЗД $(p<0,001)$.

Під час аналізу побудованих ROC-кривих (рис. 5) виявлено, що чутливість та специсрічність методів діагностики ХДЗП за допомогою $\alpha_{1}$-АТ та $\alpha_{2}-\mathrm{M}$, відповідно, становлять: $\mathrm{Se}=0,704$; $\mathrm{Sp}=1,0$ та $\mathrm{Se}=1,0 ; \mathrm{Sp}=0,828$. Для побудови $\mathrm{ROC}$-кривої $\alpha_{2}-\mathrm{M}$ не враховували даних групи хворих на хронічний гепатит з переходом у цироз у зв'язку з різкою зміною показників у них. Для
$\alpha_{1}$-АТ значення точки відсікання становить 62,5 мкмоль/л. Таким чином, значення, які перевищують цей показник, можуть свідчити про наявність патологічного стану (індекс Йодена дорівнює 0,704). Для $\alpha_{2}-\mathrm{M}$ значення точки відсікання становить 2,01 г/л. На патологічну тенденцію вказують показники, які мають нижчі значення (індекс Йодена дорівнює 0,828). AUC для $\alpha_{1}$-АТ становить $0,7852(p=0,0003)$, що свідчить про добру діагностичну інсрормативність методу; AUC для $\alpha_{2}-\mathrm{M}$ становить 0,9207 $(p=0,0004)$, що вказує на відмінну діагностичну інформативність методу.

$\alpha_{2}$-макроглобулін $€$ відомим біомаркером фріброзу печінки і важливим компонентом діагностики фріброзу цього органа у FibroTest, FIBROSpect II, Fibrometer або Hepascore. Він здатний інактивувати величезну кількість про-
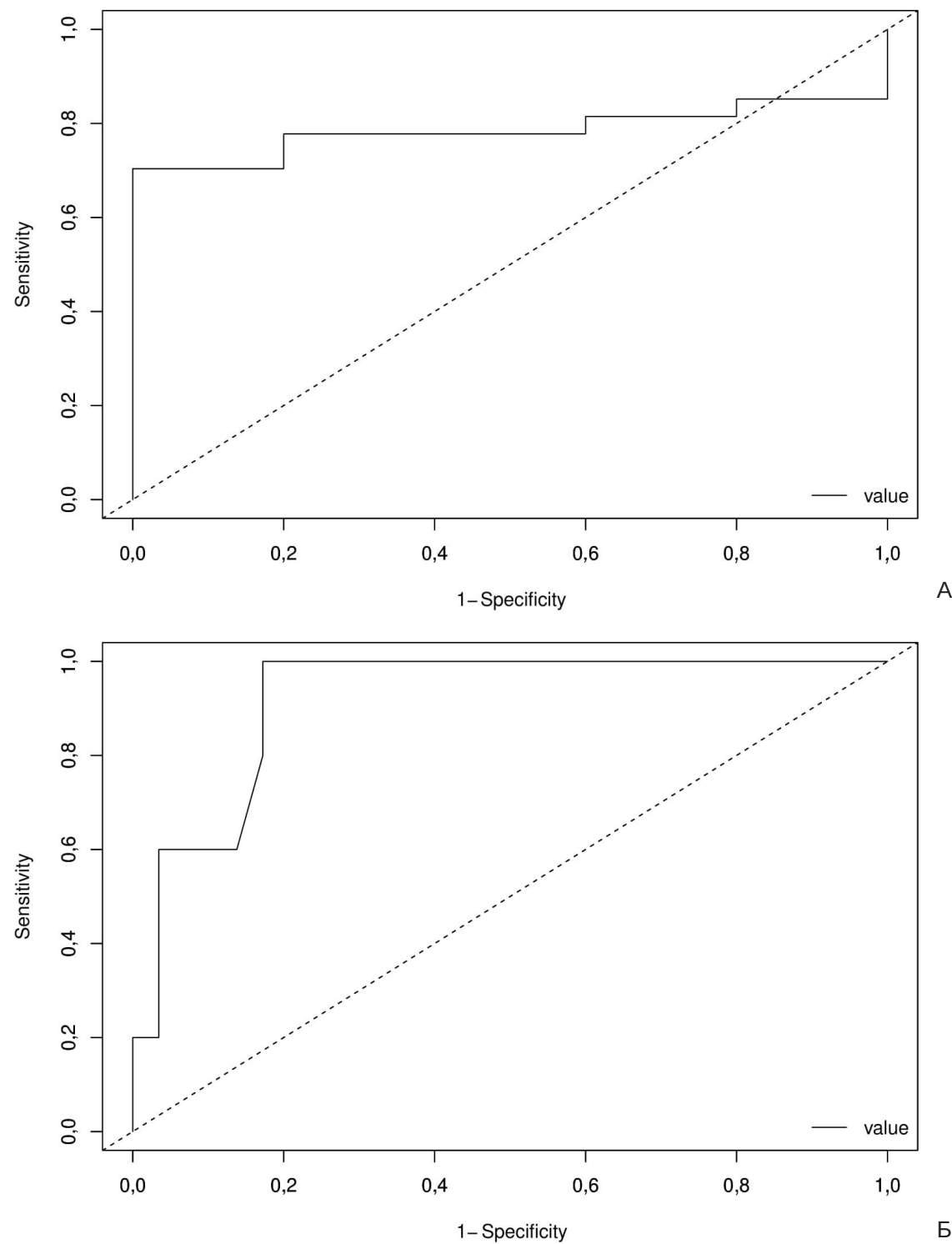

Pиc. 5. ROC-криві використання показників вмісту інгібіторів $\alpha_{1}$-антитрипсину (А) та $\alpha_{2}$-макроглобуліну (Б) у плазмі крові для діагностики хронічних захворювань печінки. 
теїназ та пригнічувати фрібриноліз за рахунок зниження рівня плазміну і калікреїну. В запаленій або ушкодженій печінці збільшення вмісту $\alpha_{2}$-макроглобуліну пригнічує катаболізм матричних протеїнів, що провокує поглиблення фріброзу [22], а стеатоз, стеатогепатит, алкогольний стеатогепатит $€$ поширеними причинами фріброзу печінки. Слід зазначити, що кореляційний аналіз виявив пряму залежність між рівнем $\alpha_{2}$-макроглобуліну та активністю катепсину В у плазмі крові пацієнтів із ХДЗП. Розрахований коефріцієнт кореляції Спірмена становив 0,71, що вказувало на сильний позитивний кореляційний зв'язок між цими показниками.

На даний час, як і раніше, біопсію печінки вважають золотим стандартом для визначення гістологічних стадій хронічних дифузних захворювань печінки. Жоден неінвазивний маркер поодинці не може еорективно диференціювати стадії ХДЗП, у тому числі стадії фріброзу та цирозу. Продукти, які накопичуються в результаті відкладення надлишкового позаклітинного матриксу, протеолітичні ензими, цитокіни та інші метаболіти, що виробляються та модисрікуються печінкою, потрапляють у кров. Зміна їх концентрації в крові може свідчити про наявність патологічного процесу в паренхімі печінки та характеризувати ступінь ушкодження органа або порушення його функції. До прямих серологічних біомаркерів хронічних дисрузних захворювань належать аланін- та аспартатамінотрансорерази, гіалуронова кислота, проколагенові пептиди I та III типів, колаген IV типу, трансфрормуючий фрактор росту $\beta$, матриксні металопротеїнази-2 і -9, інгібітор металопротеїнази-1 (TIMP-1) тощо. Ці маркери є найбільш актуальними, їх традиційно використовують для діагностики хронічних дисузних захворювань печінки [1], але триває пошук нових показників з достатнім рівнем чутливості та специфрічності. Перевагами серо-

СПИСОК ЛІТЕРАТУРИ

1. Диденко В. И. Современные методы определения фриброза печени / В.И.Диденко // Человек и лекарство. Биомедицинская химия. Казахстан. 2013. - № 13 (29). - С. 84-89.

2. Диденко В. И. Морфологическая и биохимическая оценка прогрессирования хронического гепатита, ассоциированного с вирусом С / В. И. Диденко, Н. Ю. Ошмянская, И. А. Кленина // Гастроентерологія : зб. наук. статей. - Дніпропетровськ, 2014. № 2 (52) - C. 37-41.

3. Liver fibrosis: a compilation on the biomarkers status and their significance during disease progression / логічних методів моніторингу ХДЗПє відсутність ускладнень та протипоказань, безпека, можливість використання для оцінки динаміки.

Дослідники нашої лабораторії не перший рік ведуть пошук клітинних і плазмових маркерів запальних та онкологічних процесів. При лейкемічних захворюваннях як маркери ми запропонували глікоформи деяких протеїнів гострої

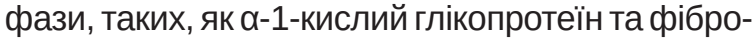
нектин [23, 24]. У цьому дослідженні ми прагнули з'ясувати, як змінюються активність цистеїнових катепсинів L, B, H і вміст інгібіторів протеолізу $\alpha_{1}$-антитрипсину та $\alpha_{2}$-макроглобуліну при хронічних дифузних захворюваннях печінки невірусної етіології, та оцінити можливість створення на основі даних показників панелі біомаркерів. Встановлені статистично значущі відмінності активностідосліджуванихцистеїнових катепсинів та вмісту плазмових інгібіторів у групах хворих на стеатогепатоз, стеатогепатит і хронічний гепатит з переходом у цироз, порівняно з групою практично здорових донорів, вказують на потенціал подальших досліджень запропонованої панелі маркерів з метою використання іiї для діагностики хронічних дифузних захворювань печінки невірусної етіології.

ВИСНОВКИ. Встановлено статистично значущі відмінності активності досліджуваних цистеїнових ензимів протеолізу і вмісту інгібіторів у плазмі крові різних груп пацієнтів із хронічними дифузними захворюваннями печінки невірусної етіології. Порівняно з групою практично здорових донорів найбільші відмінності засріксовано в групах хворих на стеатогепатоз, стеатогепатит та хронічний гепатит з переходом у цироз.

Перспективи подальших досліджень пошук оптимальної панелі плазмових біомаркерів для діагностики хронічних дисрузних захворювань печінки.

K. S. Nallagangula, S. K. Nagaraj, L. Venkataswamy, M. Chandrappa // Future Sci. - 2017. - 4 (1). DOI: 10.4155 / fsoa-2017-0083

4. MRI of diffuse liver disease: characteristics of acute and chronic diseases / S. Chundru, B. Kalb, H. ArifTiwari // Diagnostic and Interventional Radiology. - 2014. 20 (3). - P. 200-208. DOI: 10.5152/ dir.2014.13170

5. Fiore $\vee . \alpha_{v} \beta_{3}$ Integrin drives fibroblast contraction and strain stiffening of soft provisional matrix during progressive fibrosis / V. Fiore, J. Hagood, T. Barker // JCl Insight. - 2018. - 3 (20). - P. 97597. DOI: 10.1172/jci. insight.97597 
6. Cathepsin $L$ and $B$ as potential markers for liver fibrosis: insights from patients and experimental models / M. Manchanda, P. Das, G. P. Gahlot [et al.] // Clinical and Translational Gastroenterology. - 2017. - 8 (6). - P. 99. DOI: $10.1038 / \operatorname{ctg} .2017 .25$

7. Cathepsin $\mathrm{H}-$ mediated degradation of HDAC4 for matrix metalloproteinase expression in hepatic stellate cells: implications of epigenetic suppression of matrix metalloproteinases in fibrosis through stabilization of class Ila histone deacetylases / Z. Yang, Y. Liu, L. Qin [et al.] // The American Journal of Pathology. - 2017. - 187 (4). P. 781-797. DOI: 10.1016/j.ajpath.2016.12.001

8. Diagnostic values of serum cathepsin $B$ and $D$ in patients with nasopharyngeal carcinoma / G. Tan, Q. Liu, X. Tang [et al.] // BMC Cancer. - 2016. - 16, 241. DOI: 10.1186/s12885-016-2283-4

9. Evaluating the diagnostic and prognostic value of circulating cathepsin S in gastric cancer / W. L. Liu, D. Liu, K. Cheng [et al.] // Oncotarget. - 2016. - 7 (19). P. 28124-28138. DOI: 10.18632/oncotarget.8582.

10. Ellen L. Liver disease in alpha-1 antitrypsin deficiency: Current approaches and future directions / L. Ellen, Mitchell, Z. Khan // Current Pathobiology Reports. - 2017. - 5 (3). - P. 243-252. DOI: 10.1007I s40139-017-0147-5

11. Fairbanks K. D. Liver disease in alpha 1-antitrypsin deficiency: a review / K. D. Fairbanks, A. S. Tavill // American Journal of Gastroenterology. - 2008. - 103 (8). P. 2136-2141. DOI: 10.1111/j.1572-0241.2008.01955.x.

12. Bradshaw R. S. The amino acid sequence of bovine carboxypeptidase / R. S. Bradshaw, L. H. Ericsson, K. A. Walsh // Proceedings of the National Academy of Sciences. - 1969. - 63 (4). - P. 1389-1394.

13. Bradford M. M. A rapid and sensitive method for the quantification of microgramme quantities of protein utilizing the principle of protein-dye binding / M. M. Bradford // Analytical Biochemistry. - 1976. - 72. - P. 248-254.

14. Schlisterman E. F. Optimal cut-point and it's corresponding youden index to discriminate individuals using pooled blood samples / E. F. Schlisterman, N. J. Perkins, A. Liu // Epidemiology. - 2005. - 16. P. 73-81.

15. Генетически детерминированные особенности влияния молекулярной структуры отдельных изоформ фрибронектина на патогенетически значимые процессы метаболизма в организме (обзор литературы) / А. В. Долгих, О. В. Нетронина, А. С. Маслак, О. Е. Аб- раимова // Лаб. диагностика. Восточная Европа. 2018. - 7, № 3. - C. 342-359.

16. Cysteine cathepsins: From structure, function and regulation to new frontier / V. Turk, V. Stoka, O. Vasiljeva [et al.] // Biochimica et Biophysica Acta. - 2012. 1824 (1). - P. 68-88. DOI: 10.1016/j.bbapap.2011.10.002

17. Hernandez-Gea V. Pathogenesis of liver fibrosis / V. Hernandez-Gea, Friedman // Annual Review of Pathology: Mechanisms of Disease. - 2011. - 6. - P. 425-456. DOI: 10.1146/annurev-pathol-011110-130246.

18. Novinec M. Cysteine cathepsin activity regulation by glycosaminoglycans / M. Novinec, B. Lenarčič, B. Turk // BioMed Research International. - 2014. - 2. P. 309718-309719. DOI: 10.1155/2014/309718

19. Mannose receptor 2 attenuates renal fibrosis / J. M. López-Guisa, X. Cai, S. J. Collins [et al.] // Journal of the American Society of .Nephrology. -2012. - 23 (2). P. 236-251. DOI: 10.1681/ASN.2011030310

20. Cathepsin $L$ and $B$ as potential markers for liver fibrosis: insights from patients and experimental models / M. Manchanda, P. Das, G. P. Gahlot [et al.] // Clinical and Translational Gastroenterology. - 2017. - 8 (6). - P. 99. DOI: $10.1038 /$ ctg. 2017.25

21. Teckman J. H. Pathophysiology of Alpha-1 Antitrypsin Deficiency Liver Disease. Alpha-1 Antitrypsin Deficiency, Methods and Protocols / J. H. Teckman, K. S. Blomenkamp // Part of the Methods in Molecular Biology. - 2017. - 1639. - P. 1-8. DOI:https://doi. org/10.1007/978-1-4939-7163-3 1

22. Novel biomarkers predict liver fibrosis in hepatitis C patients: alpha 2 macroglobulin, vitamin D binding protein and apolipoprotein AI / A. S. Ho, C. C. Cheng, S. C. Lee [et al.] // Journal of Biomedical Science. 2010. - 17 (1). DOI: 10.1186/1423-0127-17-58

23. Содержание $\alpha-1$ кислого гликопротеина и сиаловых кислот в биологических жидкостях у больных с хроническими миелопролиферативными заболеваниями / А. С. Маслак, О.В.Костюк, И.В.Машейко, А. 3. Бразалук //Журн. Гродненского государственного медицинского университета. - 2013. - 41, № 1. С. $39-42$.

24. Маслак А. С. Степень разветвленности $\mathrm{N}$-гликанов белков плазмы у пациентов с хроническим лимсролейкозом на разных стадиях лечения / А. С. Маслак // Журн. Гродненского государственного медицинского университета. - 2013. - 44, № 4. C. 97-101.

\section{REFERENCES}

1. Didenko, V.I. (2013). Sovremennye metody opredeleniya fibroza pecheny [Modern methods for determining liver fibrosis]. Chelovek i lekarstvo. Biomedytsynskaya khimiya - Human and Medicine. Biomedical Chemistry, 13 (29), 84-89 [in Russian].

2. Didenko,V.I., Klenina, I.A., \& Oshmyanska, N.Y. (2014). Morfologicheskaya i biokhimicheskaya otsenka progressyrovaniya khronicheskogo gepatita assotsyyrovannogo s virusom "C" [Morphological and biochemical assessment of the progression of chronic hepatitis associated with the virus "C"]. Hastroenterolohiia: zbirnyk naukovykh statei - Gastroenterology: Collection of Scientific Articles, 2 (52), 37-41 [in Russian].

3. Nallagangula, K.S., Nagaraj, S. K., Venkataswamy, L., \& Chandrappa, M. (2017). Liver fibrosis: a compilation on the biomarkers status and their significance during disease progression. Future Sci., OA, 4 (1). DOI: 10.4155 / fsoa-2017-0083

4. Chundru, S., Kalb, B., Arif-Tiwari, H., Sharma, P., Costello, J., \& Martin, C.R. (2014). MRI of diffuse liver 
disease: characteristics of acute and chronic diseases. Diagnostic and Interventional Radiology, 20 (3), 200-208. DOI: $10.5152 /$ dir.2014.13170

5. Fiore, V., Hagood, J., \& Barker, T. (2018). $\alpha_{v} \beta_{3}$ Integrin drives fibroblast contraction and strain stiffening of soft provisional matrix during progressive fibrosis. $\mathrm{JCl}$ Insight, 3 (20), 97597. DOI: 10.1172/jci.insight.97597

6. Manchanda, M., Das, P., Gahlot, G.P., Singh, R., Roeb, E., Roderfeld, M., ... Chauhan, S.S. (2017). Cathepsin $L$ and $B$ as potential markers for liver fibrosis: insights from patients and experimental models. Clinica and Translational Gastroenterology, 8 (6), 99. DOI: 10.1038/ctg.2017.25

7. Yang, Z., Liu, Y., Qin, L., Wu, P., Xia, Z., Luo, M., ... Han, Y. (2017). Cathepsin $\mathrm{H}$ - mediated degradation of HDAC4 for matrix metalloproteinase expression in hepatic stellate cells: implications of epigenetic suppression of matrix metalloproteinases in fibrosis through stabilization of class Ila histone deacetylases. The American Journal of Pathology, 187 (4), 781-797. DOI: 10.1016/j.ajpath.2016.12.001

8. Tan, G., Liu, Q., Tang, X., Kang, T., Li, Y., Lu, J., ... Tang, F. (2016). Diagnostic values of serum cathepsin $B$ and $D$ in patients with nasopharyngeal carcinoma. $B M C$ Cancer, 16, 241. DOI: 10.1186/s12885-016-2283-4

9. Liu, W.L., Liu, D., Cheng, K., Liu, Y.J., Xing, S., Chi, P.D., ... Zhang, G. (2016). Evaluating the diagnostic and prognostic value of circulating cathepsin S in gastric cancer. Oncotarget, 7 (19), 28124-28138. DOI: 10.18632/ oncotarget.8582.

10. Ellen, L., Mitchell, \& Khan, Z. (2017). Liver disease in alpha-1 antitrypsin deficiency: Current approaches and future directions. Current Pathobiology Reports, 5 (3), 243-252. DOI: 10.1007/s40139-017-0147-5

11. Fairbanks, K.D., \& Tavill, A.S. (2008). Liver disease in alpha 1-antitrypsin deficiency: a review. American Journal of Gastroenterology, 103 (8), 21362141. DOI: 10.1111/j.1572-0241.2008.01955.x.

12. Bradshaw, R.S., Ericsson, L.H., \& Walsh, K.A. (1969). The amino acid sequence of bovine carboxypeptidase. Proceedings of the National Academy of Sciences, 63 (4), 1389-1394.

13. Bradford, M.M. (1976). A rapid and sensitive method for the quantification of microgramme quantities of protein utilizing the principle of protein-dye binding. Analytical Biochemistry, 72, 248-254.

14. Schlisterman, E.F., Perkins, N.J., \& Liu A. (2005). Optimal cut-point and it's corresponding youden index to discriminate individuals using pooled blood samples. Epidemiology, 16, 73-81.

15. Dolgikh, A.V., Netronina, O.V., Maslak, A.S., \& Abraymova, O.V. (2018). Genetichesky determinirovanye osobenosti vvliyaniya molekulyarnoy struktury otdelnykh izoform fibronektna na patogenicheskoy znachymye protsesy metabolizma $v$ organizme (obzor literatury) [Genetically determined features of the influence of the molecular structure of individual fibronectin isoforms on pathogenically significant metabolic processes in the body (literature review)]. Laboratornaya diagnostika. Vostochnaya Yevropa - Laboratory Diagnostics. Eastern Europe, 7 (3), 342-359 [in Russian].

16. Turk, V., Stoka, V., Vasiljeva, O., Renko, M., Sun, T., Turk, B., \& Turk, D. (2012). Cysteine cathepsins: From structure, function and regulation to new frontier. Biochimica et Biophysica Acta, 1824 (1), 68-88. DOI: 10.1016/j.bbapap.2011.10.002

17. Hernandez-Gea, V., \& Friedman, S.L. (2011). Pathogenesis of liver fibrosis. Annual Review of Pathology: Mechanisms of Disease, 6, 425-456. DOI: 10.1146/ annurev-pathol-011110-130246.

18. Novinec, M., Lenarčič, B., \& Turk, B. (2014). Cysteine cathepsin activity regulation by glycosaminoglycans. BioMed. Research International, 2, 309718309719. DOI: $10.1155 / 2014 / 309718$

19. López-Guisa, J.M., Cai, X., Collins, S.J., Yamaguchi, I., Okamura, D.M., Bugge, T.H., ... Eddy, A.A. (2012). Mannose receptor 2 attenuates renal fibrosis. Journal of the American Society of Nephrology, 23 (2), 236-251. DOI: 10.1681/ASN.2011030310

20. Manchanda, M., Das, P., Gahlot, G.P., Singh, R., Roeb, E., Roderfeld, M., ... Chauhan, S.S. (2017). Cathepsin $L$ and $B$ as potential markers for liver fibrosis: insights from patients and experimental models. Clinical and Translational Gastroenterology, 8 (6), 99. DOI: $10.1038 / \operatorname{ctg} .2017 .25$

21. Teckman, J.H., \& Blomenkamp K.S. (2017). Pathophysiology of alpha-1 antitrypsin deficiency liver disease. Alpha-1 antitrypsin deficiency, methods and protocols. Part of the Methods in Molecular Biology, 1639, 1-8. DOI:https://doi.org/10.1007/978-1-4939-7163-3_1

22. Ho, A.S., Cheng, C.C., Lee, S.C., Liu, M.L., Lee, J.Y., Wang, W.M., \& Wang, C.C. (2010). Novel biomarkers predict liver fibrosis in hepatitis $C$ patients: alpha 2 macroglobulin, vitamin D binding protein and apolipoprotein Al. Journal of Biomedical Science, 17 (1). DOI: 10.1186/1423-0127-17-58

23. Maslak, A.S., Kostyuk, O.V., Masheyko, I.V., \& Brazaluk, A.Z. (2013). Soderzhanie $\alpha$-1-kislogo glikoproteina i syalovykh kislot $v$ biologicheskikh zhidkostyakh u bolnykh s khronicheskimi meloproliferativnymi zabolevaniyami [The content of $\alpha$-1-acid glycoprotein and sialic acids in biological fluids in patients with chronic myeloproliferative disease]. Zhurnal Grodnenskogo gosudarstvennogo meditsinskogo universiteta - Journal of Grodno State Medical University, 41 (1), 39-42. [in Russian].

24. Maslak, A.S. (2013). Stepen razvetvlennosti $\mathrm{N}$-glikanov belkov plazmy u patsiyentov s khronicheskim limfoleykozom na raznykh stadiyakh lecheniya [Degree of branching of $\mathrm{N}$-glycans of plasma proteins in patients with chronic lymphocytic leukemia at different stages of treatment]. Zhurnal Grodnenskogo gosudarstvennogo mediczinskogo universiteta - Journal of Grodno State Medical University, 44 (4), 97-101 [in Russian]. 
А. В. Долгих ${ }^{1}$, А. С. Маслак ${ }^{1}$ В. И. Диденко ${ }^{2}$ И. А. Кленина ${ }^{2}$, О. Е. Абраимова ${ }^{1}$ ДНЕПРОПЕТРОВСКАЯ МЕДИЦИНСКАЯ АКАДЕМИЯ МИНИСТЕРСТВА ЗДРАВООХРАНЕНИЯ УКРАИНЫ ${ }^{1}$ ИНСТИТУТ ГАСТРОЭНТЕРОЛОГИИ НАМН УКРАИНЫ', ДНЕПР

\section{АКТИВНОСТЬ КАТЕПСИНОВ В, Ц, Н В ПЛАЗМЕ КРОВИ ПАЦИЕНТОВ С ХРОНИЧЕСКИМИ ДИФФУЗНЫМИ ЗАБОЛЕВАНИЯМИ ПЕЧЕНИ}

\section{Резюме}

Вступление. Для диагностики гистологических стадий хронических дифрфузных заболеваний печени наряду с трепанобиопсией широко используют плазменные маркеры.

Цель исследования - определить активность цистеиновых катепсинов $B, L, H$ и содержание ингибиторов протеолиза $\alpha_{1}$-антитрипсина и $\alpha_{2}$-макроглобулина в плазме крови пациентов с хроническими дифрфузными заболеваниями печени невирусной этиологии и оценить значимость этих показателей для диагностики хронических заболеваний печени.

Методы исследования. Объект исследования - плазма крови пациентов с хроническими дифрфузными заболеваниями печени $(n=51)$ в возрасте 28-60 лет, которые находились на стационарном лечении в отделении заболеваний печени и поджелудочной железы Института гастроэнтерологии НАМНУкраины. Контрольную группу составили здоровые волонтеры $(n=15)$ в возрасте от 25 до 52 лет. Активность

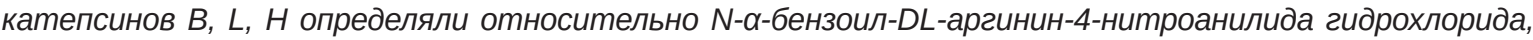
азоказеина и окситоцина соответственно. Для определения содержания ингибиторов в плазме крови в качестве субстрата использовали раствор $N$ - $\alpha$-бензоил-DL-аргинин-4-нитроанилида гидрохлорида.

Результаты и обсуждение. По сравнению с группой практически здоровых доноров статистически значимые различия зафиксированы в таких группах: у пациентов с стеатогепатитом активность катепсина В возрастала на 26,7 \%, а уровень $\alpha_{2}$-макроглобулина снижался на 30,7 \%; у больных хроническим вирусным гепатитом с переходом в цирроз активность катепсина В повышалась на 43, 8 \%, активность катепсина Н уменьшалась на 35,0 \%, а содержание $\alpha_{2}$-макроглобулина, наоборот, увеличивалось на 71,5 \%; у пациентов со стеатогепатозом активность катепсинов L и н снижалась на 22,1 и 25,0\% соответственно, а концентрация $\alpha_{1}$-антитрипсина возрастала на 19,30 \%.

Вывод. Определение уровня ингибиторов вместе с активностью цистеиновых катепсинов в плазме крови можно предложить в качестве неинвазивных маркеров при хронических дифроузных заболеваниях печени невирусной этиологии.

КЛЮЧЕВЫЕ СЛОВА: катепсины В, H, L; $\alpha_{1}$-антитрипсин; $\alpha_{2}$-макроглобулин; хронические диффузные заболевания печени; серологические биомаркеры фриброза.

H. V. Dolgikh ${ }^{1}$, H. S. Maslak', V. I. Didenko², I. A. Klenina², O. E. Abraimova ${ }^{1}$ DNIPROPETROVSK MEDICAL ACADEMY OF THE MINISTRY OF HEALTH OF UKRAINE ${ }^{1}$ INSTITUTE OF GASTROENTEROLOGY OF THE NAMS OF UKRAINE ${ }^{2}$, DNIPRO

\section{ACTIVITY OF CATHEPSINS B, L AND H IN BLOOD PLASMA IN PATIENTS WITH CHRONIC DIFFUSE LIVER DISEASES}

\section{Summary}

Introduction. Plasma markers are widely used along with trepanobiopsy to diagnose the histological stages of chronic diffuse liver diseases.

The aim of the study - to determine the activity of cysteine cathepsins $B, L, H$ and the content of proteolysis inhibitors $\alpha_{1}$-antitrinsin and $\alpha_{2}$-macroglobulin in the blood plasma of patients with chronic diffuse liver diseases of non-viral etiology.

Research Methods. The object of research is the blood plasma of patients with chronic diffuse liver diseases ( $n=51$ ) aged 28-60 years hospitalized in the Department of Liver and Pancreas Diseases of the Institute of Gastroenterology of the National Academy of Medical Sciences of Ukraine. The control group consisted of healthy volunteers $(n=15)$ aged from 25 to 52 years. The activity of cathepsins $B, L$ and $H$ were determined relatively to $N$ - $\alpha$-benzoyl-DL-arginine-4-nitroanilide hydrochloride, to azocasein and to oxytocin, respectively. The solution of $N$ - $\alpha$-benzoyl-DL-arginine-4-nitroanilide hydrochloride was used as a substrate for determination the content of inhibitors in human blood plasma.

Results and Discussion. Compared with the group of practically healthy donors, statistically significant differences were recorded in: patients with steatohepatitis, the activity of cathepsin B increases by $26.7 \%$, and the 
level of $\alpha_{2}$-macroglobulin decreases by $30.7 \%$; in patients with chronic viral hepatitis with transition to cirrhosis, the activity of cathepsin B increases by $43.8 \%$, the activity level of cathepsin $\mathrm{H}$ decreases by $35 \%$, and the content of $\alpha_{2}$-macroglobulin, on the contrary, increases by $71.5 \%$; in the group of patients with steatohepatosis, the activity of cathepsin $L$ and $H$ decreases by $22.1 \%$ and $25 \%$, respectively, and the concentration of $\alpha_{1}$-antitrypsin increases by $19.3 \%$.

Conclusions. Determination of the content of inhibitors in conjunction with the activity of cysteine cathepsin in blood plasma can be proposed as non-invasive markers for chronic diffuse liver diseases of non-viral etiology.

KEY WORDS: cathepsin B; cathepsin H; cathepsin L; $\alpha_{1}$-antitrypsin; $\alpha_{2}$-macroglobulin; chronic diffuse liver diseases; serological fibrosis biomarkers.

Отримано 23.01.20

Адреса для листування: Г. С. Маслак, Дніпропетровська медична академія Міністерства охорони здоров'я України, вул. Володимира Вернадського, 9, Дніпро́, 49044, Україна, e-mail: gannamaslak@gmail.com. 